\title{
correspondence
}

\section{Temporary contracts}

SiR,--In the editorial (29 June, page 265) you deplore the present legal restrictions on temporary research contracts as "another small restraint (which) has been imposed on freedom to do research". The question is - freedom for whom?

I have been working for ten years as a (untenured) research fellow in the field of ultra cold ncutrons. During this time I have achieved something of an international reputation and have made at least two contributions which have significantly altered the direction of research in this field. In spite of this I find that, due to the attitude of scientific administrators in this country to untenured researchers it is necesssary for me to enter into collaboration with groups from other countries (in particular France, Germany and the USA) in order to sec my ideas put into practice. In addition I must face the fact that my career as a researcher can be effectively terminated at the whim of a single professor who can simply refusc to apply for an extension to my research grant. There are at least three other people in this department in almost identical situations.

I think you and your readers shoukt realise that the freedom of which you speak is bought at a terrible price, a price that is being paid by myself and my colleagues and I would ask you to be more tolerant towards a legal situation which offers us at least token support.

Yours faithfully,

ROBERT Golur

University of Sussex,

Brighton, UK

\section{Burying high level wastes}

Sir,-The reaction by Brookins et al. (29 June. page 704) to my suggestion (16 February, page 605) that conventional gcochronological measurements might be more widely emploved in the selection and evaluation of evaporite deposits for high-level radioactive waste disposal is based on a misinterpretation. It was certainly never stated either that "geochronologic K-Ar data argue against the suitability of bedded salt deposits" for this purpose or that afl deposits, such as the New Mexico occurrence being considered as a waste repository, had been recently recrystallised by percolating groundwaters. On the contrary the limited results presented by these correspondents go some way towards illustrating the potential usefulness of isotopic techniques in evaporites' evaluation.

That sulvite, a predominant mineral in some evaporites, loses radiogenic argon with the passage of time is "wellrecognised" by the authors and is substantiated by their own results on the samples from Los Medanos and those of Polevaya et al. (Geochem. 8, 897-906. 1958). It is well-known that loss of a radiogenic isotope often occurs from the principal rock-forming mineral in some salt deposits. This surely is the all- important point to be considered when discussing the suitability of these rocks for radioactive waste disposal.

The mechanism of loss is a secondary consideration. If diffusion is the favoured operative process, as has been implied, it is surprising that identical coegenetic crystals from the same deposit have different argon contents at the present time (as appears to be the case with the syivites from the Los Medanos deposit, for example). Other loss promoting processes, such as recrystallisation (Polevaya et al) require consideration and it would therefore be of considerable interest to examine their bulk distribution and timing through a systematic programme of argon measurements.

That the rare mineral langbeinite is highly retentive of radiogenic argon has been known for over a decade (Lippolt, H. J. and Oesterle, F. P. (Naturwiss 64, 90; 1977 and references therein) so it comes as no surprise that the 'correct' age was obtained for the single Los Medanos sample. Unfortunately this is of little consequence as no proposals have been alvanced to dispose of radioactive waste in monomineralic deposits of this type.

In summary it is misleading of Brookins et al. to blandly dismiss the $\mathrm{K}-\mathrm{Ar}$ evidence and attribute the results solely to a selective diffusion process (which operated exclusively on gas atoms in sylvites). This attitude only cncourages others (eg Cohen, Rev. Mod. Phy's. 49, 10, 1977) to state that (for salt beds) "their very existence over time spans like $250 \mathrm{Myr}$ is proof that water has not entered them". Such pronouncements require scientific justification and I reitcrate my point that detailed geochronological investigations would appear capable of assisting in the location of those potential salt repositories offering maximum security. Yours faithfully,

R. M. MACINTYRE.

University of Strathclyde. UK

\section{Saccharin}

Sir.-B. L. Cohen makes an erroneous assumption in his letter on saccharin (29 June, page 704) when he assumes that "it would be highly beneficial to the public if the food processing industry "were to substitute saccharin for sugar". His assumption is that the consumption of food calories would diminish by an amount equal to the sugar calories of sweetened foods, if saccharin were substituted for sugar. What would happen, of course is that the same number of calories would be consumed in a different form, by eating the same weight of food, because food is eaten to supply calories. If the article of food were high in fat, the hazard to health might be increased.

\section{Yours faithfully,}

THOMAS H. JUKES

University of California.

Berkeley, USA

\section{Human rights world-wide}

SIR.-As scientists concerned about human rights, we are disturbed by the recent boycoul by United States physicists of conferences in the Soviet Union. Their action reflects the current political climate that stems largely from the Carter administration's policy on human rights. However, while the "Human Rights Campaign" vociferously condemns trials of dissidents in the Soviet Union, it ignores or minimises flagrant violations of human rights in South Korea, Iran, and other allied countries for reasons of "national security". This campaign is equally inconsistent in its steadfast refusal to recognise violations of human rights in the United States.

We believe it is our duty first to protest human-rights violations in our own country. The case of the Wilmington ten has becn cited by Amnesty International (recipient of a Nobel Peace Prize) as a violation of human rights. Ten civil rights workers, eight of them high school students. demanding equal education in Wilmington, North Carolina, defended a church from armed attack by the Ku Klux Klan in 1971 and subsequently were framed on an arson charge. The Wilmington ten are serving prison sentences averaging 28 years and have been political prisoners now for more than two vears. Seventy-five Congress-men and women have asked US Attorney General Griffin Bell to intervene. Church, community, labour, and political leaders in this country and abroad are

demanding their release. Nor is this an isolated case. The human and constitutional rights of native American Indians. Spanish-speaking Americans, black Americans, women, and members of specific political groups are infringed daily

Is it not hypocritical for Americans to condemn the Soviet Union when our own country is culpable? Certainly criticism of other nations would be more convincing were the domestic record not so flawed.

We are dismaved that American physicists have chosen to follow our government's policy of directing attention away from injustices in the United States by trying to focus it abroad. Such actions are even more regrettable in view of the prolonged and extensive efforts by American scientists to establish programmes of cooperation and exchange with their Soviet colleagues. Rather than a demonstration of support for worldwide human rights, the boveott abets the masking of violations.

Yours faithfully, Roy S. ChalefF Henry S. LOWENDORT

Cornell University.

New York, USA 